\title{
$\alpha 1,3$ Fucosyltransferase VII plays a role in colorectal carcinoma metastases by promoting the carbohydration of glycoprotein CD24
}

\author{
WENHUA LI ${ }^{1,6}$, WEN ZHANG ${ }^{1,6}$, JIANMING LUO ${ }^{4,6}$, AYONG CAO ${ }^{4,6}$, YING ZHANG ${ }^{5,6}$, \\ DAN HUANG ${ }^{2,6}$, WEIQI SHENG ${ }^{2}$, SANJUN CAI $^{3,6}$ and JIN LI ${ }^{1,6}$ \\ Departments of ${ }^{1}$ Medical Oncology, ${ }^{2}$ Pathology and ${ }^{3}$ Colorectal Surgery, ${ }^{4}$ Department of Breast Surgery, \\ Breast Cancer Institute, Fudan University Shanghai Cancer Center; ${ }^{5}$ Key Laboratory of Glycoconjugate Research, \\ Ministry of Health-Department of Biochemistry and Molecular Biology, ${ }^{6}$ Department of Oncology, \\ Shanghai Medical College, Fudan University, Shanghai 200032, P.R. China
}

Received January 13, 2010; Accepted February 22, 2010

DOI: $10.3892 /$ or_00000802

\begin{abstract}
Changes in the expression levels of $\alpha 1,3$ FucT-VII and carbohydrate product $\mathrm{SLe}^{\mathrm{X}}$ have been reported in certain types of malignant transformations. However, the specific role of FucT-VII in human colorectal carcinoma is still not clear. We evaluated the expression of FucT-VII in tumor specimens from 30 colorectal carcinoma patients by RT-PCR and immunohistochemistry. The alteration of metastatic potential of LOVO cells before and after $\alpha 1,3$ FucT-VII gene transfection was also assayed. The expression change of glycoprotein CD24 and carbohydrate antigen SLe ${ }^{\mathrm{X}}$ after stable transfection of LOVO was also examined in vitro. Higher mRNA and protein expression of FucT-VII were observed in colorectal tumors compared with adjacent normal ones. The cell chemotactic migration and invasion were enhanced after $\alpha 1,3$ FucT-VII transfection in LOVO cells. There was a positive correlation between $\alpha 1,3$ FucT-VII mRNA expression and lymph node status $(\mathrm{p}=0.009)$ and AJCC stage $(p=0.007)$, similar correlation was also observed at protein level ( $\mathrm{p}=0.042$ and 0.022 , respectively). Overexpression of $\alpha 1,3$ FucT-VII promoted the expression of CD24 and $\mathrm{SLe}^{\mathrm{X}}$ in LOVO cells. Our findings suggest that $\alpha 1,3$ FucT-VII might play a role in colorectal carcinoma metastases by promoting the carbohydration of glycoprotein CD24.
\end{abstract}

\section{Introduction}

Colorectal cancer is the leading malignancy in western countries and its incidence has increased recently in some big

Correspondence to: Dr Wen Zhang, Department of Medical Oncology, Fudan University Shanghai Cancer Center, 270 Dong An Road, Shanghai 200032, P.R. China

E-mail:0256206@fudan.edu.cn; zhangwen_a@hotmail.com

Key words: $\alpha 1,3$ Fucosyltransferase VII, colorectal carcinoma, metastasis, CD24, sialyl Lewis X cities in China (1). Although $40-50 \%$ of the patients in the early stages could be cured surgically, the treatment failures are usually owed to distant metastasis. Tumor metastasis is a multi-step complex process involving a variety of molecules participating. The adhesion between tumor cell and vesicular endothelial cell or extracellular matrix, and the migration and invasion of cells are pivot events in metastasis (2).

Aberrant carbohydration is an important mechanism for tumor metastasis. The carbohydrate moieties of cell surface glycoconjugates play an important role in cell-cell and cellmolecular recognition, such as receptor combination, signaling pathway and molecular, which may lead to a variety of biological alterations in cells (3). Aberrant cell surface glycosylation patterns, a hall mark of oncogenic transformation and malignant phenotype of tumor cells, lead to alterations in cell-cell and cell-matrix interaction by affecting the function of adhesion molecules (4). The two most commonly observed aberrant $\mathrm{N}$-glycosylations in experimental tumor models are an increase in terminal sialylation and a shift to more highly branched N-linked oligosaccharides (4-6).

Fucosyltransferase (FucT) is a family of glycosyltransferases responsible for the synthesis of fucosyl-containing compounds, including the A, B and O blood groups and Lewis antigens. It catalyzes the transfer of a fucosyl residue from GDP- $\alpha$-L-fucose to a sugar acceptor, usually galactose or $\mathrm{N}$-acetylglucosamine, in the sugar chains of glycoproteins or glycolipids (7). Nine subgroups of $\alpha$-fucosyltransferase have been cloned. Among these subclones, $\alpha 1,3$ Fucosyltransferase VII (FucT-VII) fucosylates sialylated acceptors and produces sialyl Lewis $X\left(\operatorname{SLe}^{\mathrm{X}}\right)$ antigens only $(7,8)$. Fucosylated carbohydrate structures are involved in a variety of biochemical and pathological processes, especially close to tumor invasion and metastases (9). For example, high expression of $\alpha 1,6$ FucT was found to be related to the degree of infiltration through the intestinal wall, and higher enzyme activity was observed in high grade tumors with lymph node metastases (10); While lower gene copies of FucT-III were observed in more invasive tumors with distant metastases (11). 
FucT-VII was proved to play a predominant role in regulating the interaction of PSGL-1 with selectins (12) and producing cancer related carbohydrate gene SLe ${ }^{\mathrm{X}}$. Moreover, several alterations of FucT-VII during carcinogenesis have been reported (13-17). High gene copies of FucT-VII were found to be correlated to lymph node metastases in breast cancer, with a better 5-year survival rate in patients with strong expression than those with low or negative expression (13). The expression of FucT-VII was also increased in pancreatic cancer (14), lung cancer (15) and hepatocarcinoma (16), and the down-regulation of it was one of the mechanisms to explain the metastasis-suppressive effect of the nm23-H1 gene (17).

As a known cancer-related gene, $\mathrm{SLe}^{\mathrm{X}}$ was previously found to express at high level in colorectal cancer and predicted an ominent prognosis and high risk of recurrence (18). SLe ${ }^{\mathrm{X}}$ modified CD24 was suggested to be an essential factor for the progression of tumor metastases (19). Previous research has revealed that CD24 was a new diagnostic marker of tumors and possibly participated in tumor metastasis and correlated to survival (19-24).

The role of FucT-VII in human colorectal carcinoma remains unclear. Here we combined immunohistochemistry, RT-PCR and Western blotting techniques to elucidate whether the expression of FucT-VII was up-regulated in colorectal cancer. We also evaluated the correlation between the expression of FucT-VII and metastatic potential. Our results revealed that FucT-VII was more highly expressed in colorectal cancer than in adjacent normal tissues and closely related to lymph node metastases. Therefore, this fucosyltransferase could play an important role in the metastatic progression of colorectal cancer.

\section{Materials and methods}

Patients and specimens. Thirty patients were diagnosed with colorectal carcinoma pathologically and had surgical treatment in the Department of Colorectal Cancer, Fudan University Shanghai Cancer Center between May 2007 and August 2007. All the patients had signed consent forms and the primary tumor specimens and adjacent normal tissues were stored in the tissue bank of the hospital. Data for clinical characteristics was obtained through in-patient records. The last date of follow-up was January 1, 2009. The median follow-up time was 18 months. The survival status of each patient was confirmed by telephone contact or clinical visit.

Reagents and cell lines. RPMI-1640 medium and fetal bovine serum (FBS) were purchased from Gibco/BRL. The plasmid pcDNA3.0 containing $\alpha 1,3$ FucT-VII cDNA was kindly provided by Professor Narimatsu H. (Soka University, Japan).

LOVO cell line was obtained from ATCC, and was cultured in RPMI-1640 medium supplemented with $10 \%$ FBS. The cultures were incubated at $37^{\circ} \mathrm{C}$ in a humidified $5 \% \mathrm{CO}_{2}$ atmosphere.

Stable transfections. The plasmid pcDNA3.0 with or without $\alpha 1,3$ FucT-VII were transfected using the Lipofectamine reagent (Life Technologies, Inc., Rockville, MD, USA). G418 sulfate (geneticin)-resistant colonies were selected in medium with G418 (1000 $\mu \mathrm{g} / \mathrm{ml})$ and expanded. The FucT-VII positive colonies were identified by RT-PCR and Western blotting.

\section{Expression analysis of $\alpha 1,3$ FucT-VII transfectants}

RNA isolation and RT-PCR analysis. Total RNA was isolated from FucT-VII, mock-transfected and control cells using TRIzol reagent (Life Technologies, Inc., Gaithersburg) according to the reagent protocol. The RNA purification (D260/D280 1.8-2.0) and concentration were tested by DU800UV/Vis Spectrophotometer. Total RNA (2 $\mu \mathrm{g})$ was converted to cDNA using the RevertAid ${ }^{\mathrm{TM}}$ First Strand cDNA Synthesisi kit. One microliter of each RT reaction mixture was applied to $25 \mu \mathrm{l}$ of PCR mixture, containing $0.5 \mu 1$ Taq DNA polymerase (Fermentas Life Science), $1.5 \mu 1$ $\mathrm{MgCl}_{2}, 2.5 \mu \mathrm{l}$ Taq buffer, $0.5 \mu 1 \mathrm{dNTPs}$ and $0.5 \mu 1$ up and down primers. The primers of FucT-VII were 5'-CACCTCC GAGGCATCTTCAACTG-3' and 5'-CGTTGGTATCGGCT CTCATTCATG-3', 497 bp; those of CD24 were 5'-ATGGG CAGAGCAATGGTG-3' and 5'-GAGTAGAGATGCAGAA GAGAGA-3', 243 bp; and GAPDH were 5'-TGAACGGGA AGCTCACTGG-3' and 5'-TCCACCACCCTGTTGCTGC TGTA-3', $307 \mathrm{bp}$. The annealing temperatures of FucT-VII, CD24 and GAPDH were 58,58 and $56^{\circ} \mathrm{C}$, respectively. A total of 30,30 and 28 cycles of PCR were carried out for FucT-VII, CD24 and GAPDH.

The PCR products were electrophoresed on $1.5 \%$ agarose gel and then imaged on an ChemiImage 5500 Imaging System (Alpha Innotech, San Leandro, CA, USA). To compare the mRNA relative expression, densitometry of FucTVII/GAPDH, or CD24/GAPDH, which was perfomed using the ChemiImager 5500, was used to semi-quantify RT-PCR.

Western blotting. Cells were washed three times with icecold PBS and lysed in cell lysis solution (Jingmei Biotech, China). Cells were shaked in ice for $30 \mathrm{~min}$ and insoluble debris was removed by centrifugation at $13000 \mathrm{rpm}$ for $60 \mathrm{~min}$. Proteins $(50 \mu \mathrm{g})$ were analysed by $10 \%$ SDS-PAGE. After electrophoresis, proteins were transferred to a polyvinylindene difluoride membrane, and the membrane was blocked with $5 \%$ BSA in PBS. The blots were probed with goat anti-human FucT-VII antibody (L-14, Santa Cruz) diluted 1:1000, and then incubated with a horseradish-peroxidase conjugated rabbit anti-goat IgG antibody (Dako Cytomation) diluted $1: 2000$. Normalization of protein loading was done with GAPDH (mouse anti-GAPD McAb, PtgLab).

Immunohistochemistry. Formalin-fixed paraffin-embedded tissue was freshly cut $(4 \mu \mathrm{m})$. Antigen retrieval was achieved by pressure cooking in $0.01 \mathrm{~mol} / 1$ citrate buffer for $20 \mathrm{~min}$. The primary CD24 antibody (Ab-2, clone SN3b, Neomarkers, Fremont, CA) was diluted 1:50, SLe $^{\mathrm{X}}$ antibody (KM93, Chemicon) was diluted 1:50, FucT-VII antibody (L-14, Santa Cruz) was diluted 1:30, and was incubated at room temperature for one night. Detection took place by anti-mouse IgM antibody labeled with peroxidase $(N$-Histofine Simple Stain MAX PO, Nichirei Bioscience, Inc.) and SABC anti-goat IgG antibody (Boster Co.) for $30 \mathrm{~min}$ at room temperature and colorimetric detection with 3,3'-diaminobenzidine (DAB). Afterwards the slides were briefly counterstained with hematoxylin and aqueously mounted. 


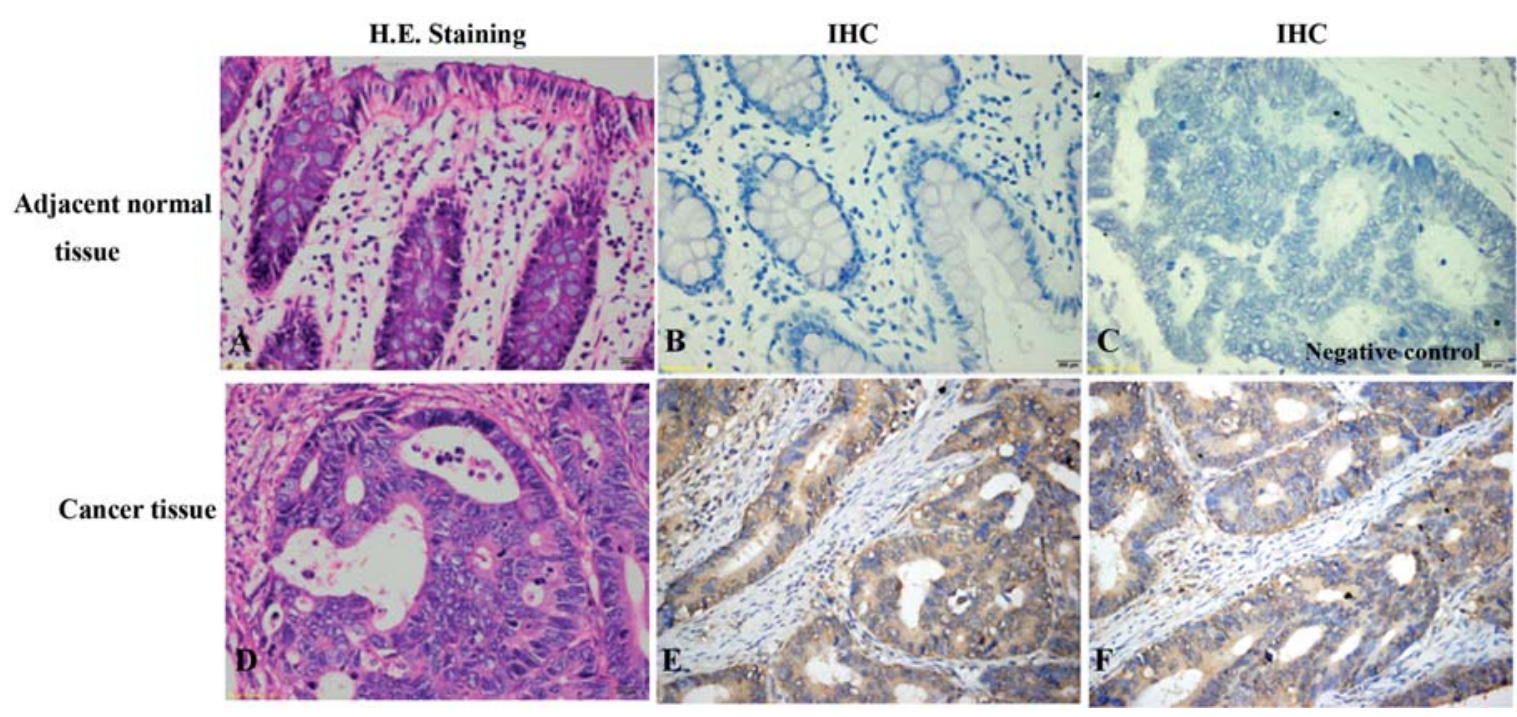

Figure 1. FucT-VII immunohistochemistry in colorectal cancer. (A) H\&E staining of adjacent normal tissue. (B) Negative expression in adjacent normal tissue. (C) Negative control of cancer tissue. (D) H\&E staining of cancer tissue. (E) and (F) Cytoplasmic overexpression of FucT-VII in the colorectal cancer tissue $(\mathrm{x} 400)$.

Immunostaining of tissue slides was independently evaluated by two clinical pathologists who were unaware of patient outcome. As CD24 showed a cytoplasmic and membranous staining, we scored staining qualities as either negative or weakly, moderately or strongly positive. The FucT-VII expression was evaluated by scoring negative or positive.

The cell immunoblot was similarly performed in the slices covered by acetone-fixed cells. The primary CD24 antibody (Ab-2, clone SN3b, Neomarkers) was diluted 1:50, FucT-VII antibody (L-14, Santa Cruz) was diluted 1:50, followed by the same procedures as above.

Detection of SLe ${ }^{X}$ and CD24 antigens with flow cytometry. The cells $\left(1 \times 10^{6}\right)$ were detached with $0.25 \%$ trypsin-EDTA (Gibco), washed and re-suspended in PBS, then incubated with anti-SLe ${ }^{\mathrm{X}}$ monoclonal antibodies (KM93, Chemicon) in 1:50 dilution or CD24 antibody (Ab-2, clone SN3b, Neomarkers) in 1:50 dilution, for $30 \mathrm{~min}$ at $4^{\circ} \mathrm{C}$. After two washes, the cells were incubated for $45 \mathrm{~min}$ at $4^{\circ} \mathrm{C}$ with work solution of FITC-conjugated goat anti-mouse IgM (Sigma). Then the cells were subjected to fluorescence analysis performed on Becton-Dickinson FACS Calibur machine. Fluorescence activated cell spectra were drawn automatically, and the left- or right-shift of the curve or its peak indicated the decrease or increase of the mean fluorescence intensity, respectively, quantitative data were expressed as the mean fluorescence intensities of the positive cells in the experiments.

Cell migration and invasion assay. Cell migration assay was performed using 24-well transwell units (Corning Incorp., USA). Each lower compartment of the transwell units contained $600 \mu 1$ of $10 \%$ FBS in RPMI-1640 and cells $\left(5 \times 10^{4}\right)$ in $100 \mu 1$ DMPI-1640 were added into the upper compartment of the transwell units, and then incubated for $18 \mathrm{~h}$ at $37^{\circ} \mathrm{C}$ in a humidified atmosphere containing $5 \% \mathrm{CO}_{2}$. The cells were fixed with $10 \%$ formaldehyde and stained with $\mathrm{H} \& \mathrm{E}$. The numbers of the cells that migrated to the lower side of the polycarbonate filter were counted in 8 HPFs (x400). The data were expressed by the mean number of cells per HPF with two independent experiments.

Cell invasion assay was similarly performed, except that the upper side of polycarbonate filter was coated with matrigel (in proportion of 1:3 with RPMI-1640) to form a continuous thin layer. Cells $\left(1 \times 10^{5}\right)$ in $100 \mu$ l RPMI-1640 were added, and the incubation time prolonged to $24 \mathrm{~h}$. Cells were stained and counted as described above, and the number of cells that invaded the lower side of the filter was a measure of the invasive activity of the cells.

Statistical analysis. The data were compiled with the software Stata, version 7.0. Student's t-test and analysis of variance were used to determine the statistical significance of difference between experimental groups, and Kruskal-Wallis $H$ test was used with unequal variances. Fisher's exact test and $\chi^{2}$ test for trend was used to assess the statistical significance of associations between the protein expression and clinicopathologic variables. Spearman rank coefficient was used to assess the correlation between the mRNA expression of CD24 and FucT-VII. $\mathrm{P}<0.05$ was considered a significant association.

\section{Results}

High expression of $\alpha 1,3$ FucT-VII and its association with the lymph node metastasis in colorectal cancer patients. A total of 30 colorectal cancer patients were analyzed. The mRNA expression of FucT-VII was significantly higher in colorectal carcinoma tissue than that in adjacent normal tissue (FucTVII/GAPDH: $0.124 \pm 0.110$ vs. $0.077 \pm 0.033$, p<0.05). The rate of positive expression of protein was significantly higher in tumor tissue than that in the adjacent normal ones (83.3 vs. $\left.26.7 \%, \chi^{2}=19.461, p=0.000\right)$. FucT-VII was positively stained in cytoplasm of the cells (Fig. 1)

As shown in Table I, there was a positive correlation between FucT-VII mRNA expression and lymph node status 
Table I. Associations between $\alpha 1,3$ FucT-VII mRNA and clinicopathologic variables.

\begin{tabular}{lccc}
\hline Characteristic & $\begin{array}{c}\text { Cases } \\
(\mathrm{n})\end{array}$ & $\begin{array}{c}\alpha 1,3 \text { FucT-VII/ } \\
\text { GAPDH }\end{array}$ & P-value \\
\hline 30 & $0.124 \pm 0.110$ &
\end{tabular}

$\begin{array}{ll}16 & 0.119 \pm 0.082 \\ 14 & 0.129 \pm 0.139\end{array}$

$\geq 60$

Differentiation

$\begin{array}{lrr}\text { High } & 5 & 0.097 \pm 0.012 \\ \text { Moderate } & 18 & 0.133 \pm 0.134 \\ \text { Low } & 7 & 0.120 \pm 0.081\end{array}$

Serous layer

invasion

$\begin{array}{lrrr}\text { No } & 9 & 0.088 \pm 0.052 & 0.251^{\mathrm{a}} \\ \text { Yes } & 21 & 0.139 \pm 0.125 & \end{array}$

Dukes

$\begin{array}{lll}\text { A } & 7 & 0.065 \pm 0.026 \\ \text { B } & 7 & 0.082 \pm 0.030 \\ \text { C } & 8 & 0.157 \pm 0.058 \\ \text { D } & 8 & 0.180 \pm 0.188\end{array}$

Tumor stage

$\begin{array}{lrr}\mathrm{pT}_{1-2} & 8 & 0.095 \pm 0.051 \\ \mathrm{pT}_{3} & 9 & 0.092 \pm 0.047 \\ \mathrm{pT}_{4} & 13 & 0.164 \pm 0.152\end{array}$

Nodal status

$\begin{array}{lll}\mathrm{pN}_{0} & 15 & 0.073 \pm 0.027 \\ \mathrm{pN}_{1-2} & 15 & 0.175 \pm 0.137\end{array}$

Distant metastasis

$\begin{array}{lrrr}\mathrm{pM}_{0} & 22 & 0.103 \pm 0.058 & 0.091^{\mathrm{a}} \\ \mathrm{pM}_{1} & 8 & 0.180 \pm 0.188 & \end{array}$

Grade

\begin{tabular}{llll} 
I & 6 & $0.070 \pm 0.024$ & $0.007^{\mathrm{b}}$ \\
II & 8 & $0.075 \pm 0.032$ & \\
III & 8 & $0.157 \pm 0.058$ & \\
IV & 8 & $0.180 \pm 0.188$ \\
\hline
\end{tabular}

at-test; 'Kruskal-Wallis $H$ test.

$(\mathrm{p}=0.009)$, AJCC stage $(\mathrm{p}=0.007)$ and Dukes stage $(\mathrm{p}=0.005)$. FucT-VII protein expression was also correlated to lymph node status $(\mathrm{p}=0.042)$ and AJCC stage $(\mathrm{p}=0.022)$ (Table II).

Stable transfection of a 1,3 FucT-VII cDNA in LOVO cells. We found a weak expression of FucT-VII at both mRNA and protein level in LOVO cells. Up-regulation of FucT-VII expression in colorectal carcinoma cells might have changed the biological behaviors of LOVO cells, thus enhance the tumor metastatic potential. To verify our speculation, we
Table II. Associations between FucT-VII protein expression and clinicopathologic variables.

\begin{tabular}{lcccr}
\hline Characteristic & $\begin{array}{c}\text { Cases } \\
(\mathrm{n})\end{array}$ & $\begin{array}{c}\text { FucT-VII } \\
\text { negative }\end{array}$ & $\begin{array}{c}\text { FucT-VII } \\
\text { positive }\end{array}$ & P-value \\
& & 8 & 22 & \\
Age (years) & & & & \\
$\quad<60$ & 16 & 2 & 14 & $0.642^{\mathrm{a}}$ \\
$\geq 60$ & 14 & 3 & 11 & \\
Differentiation & & & & \\
$\quad$ High & 5 & 1 & 4 & $0.399^{\mathrm{b}}$ \\
$\quad$ Moderate & 18 & 4 & 14 & \\
Low & 7 & 0 & 7 &
\end{tabular}

Serous layer

invasion

$\begin{array}{lrrr}\text { No } & 9 & 2 & 7 \\ \text { Yes } & 21 & 3 & 18\end{array}$

Dukes

$\begin{array}{llll}\text { A } & 7 & 2 & 5 \\ \text { B } & 7 & 3 & 4 \\ \text { C } & 8 & 0 & 8 \\ \text { D } & 8 & 0 & 8\end{array}$

Tumor stage

$\begin{array}{lrrr}\mathrm{pT}_{1-2} & 8 & 1 & 7 \\ \mathrm{pT}_{3} & 9 & 3 & 6 \\ \mathrm{pT}_{4} & 13 & 1 & 12\end{array}$

Nodal status

$\begin{array}{lllll}\mathrm{pN}_{0} & 15 & 5 & 10 & 0.042^{\mathrm{a}} \\ \mathrm{pN}_{1-2} & 15 & 0 & 15 & \end{array}$

Distant metastasis

$\begin{array}{lrrrr}\mathrm{pM}_{0} & 22 & 5 & 17 & 0.287^{\mathrm{a}} \\ \mathrm{pM}_{1} & 8 & 0 & 8 & \end{array}$

Grade

$\begin{array}{lllll}\text { I } & 6 & 1 & 5 & 0.022^{\mathrm{b}} \\ \text { II } & 8 & 4 & 4 & \\ \text { III } & 8 & 0 & 8 & \\ \text { IV } & 8 & 0 & 8 & \end{array}$

${ }^{\mathrm{a}}$ Fisher's exact test; ${ }^{\mathrm{b}} \chi^{2}$ test for trend.

transfected an $\alpha 1,3$ FucT-VII expression vector into LOVO cells and generated stable transfectants. FucT-VII exhibited a strong cytoplasmic immunostaining in transfected LOVO cells (Fig. 2). FucT-VII transfectant clones from LOVO cells expressing high levels of FUT7 protein and named LOVO/ FucT-VII were used in further experiments.

Increase of the migration and invasion of LOVO cells transfected with a1,3 FucT-VII. In FucT-VII-transfected LOVO cells, the ability of chemotactic migration through trans-well 
A

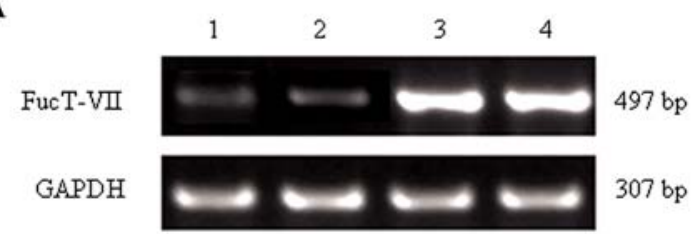

B

FucT-VII

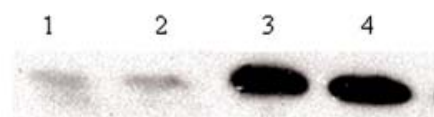

$39.2 \mathrm{kDa}$
C

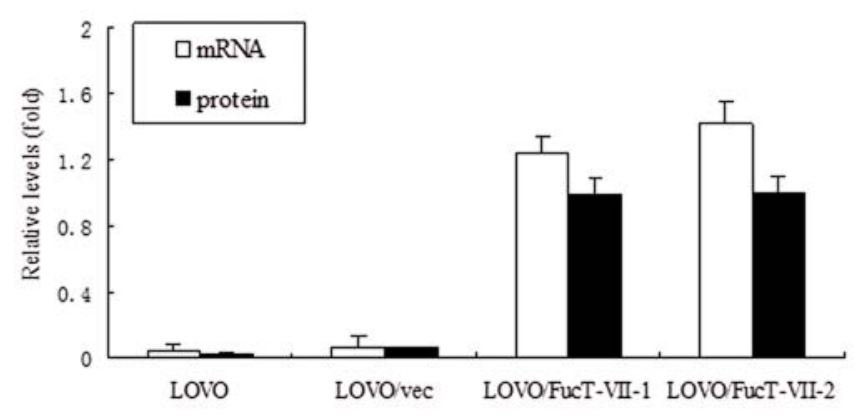

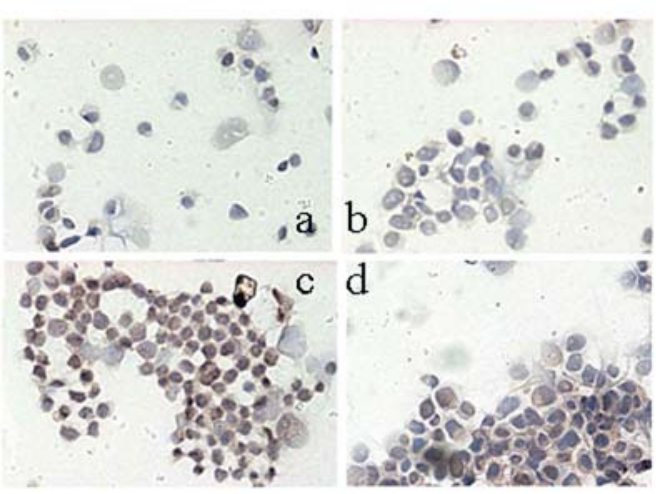

Figure 2. Expression of FucT-VII in LOVO cells after transfection. (A) RT-PCR. Lane 1, LOVO; Lane 2, LOVO/vec; Lane 3, LOVO/FucT-VII clone 1; Lane 4, LOVO/FucT-VII clone 2. (B) Western blotting. Lane 1, LOVO; Lane 2, LOVO/vec; Lane 3, LOVO/FucT-VII clone1; Lane 4, LOVO/FucT-VII clone 2. (C) The relative expression of FucT-VII mRNA and protein. Representative quantitation of three independent experiments. The error bars represent the SE. (D) Cell immunostaining (x100). (a) LOVO; (b) LOVO/vec; (c) LOVO/FucT-VII clone 1; (d) LOVO/FucT-VII clone 2.

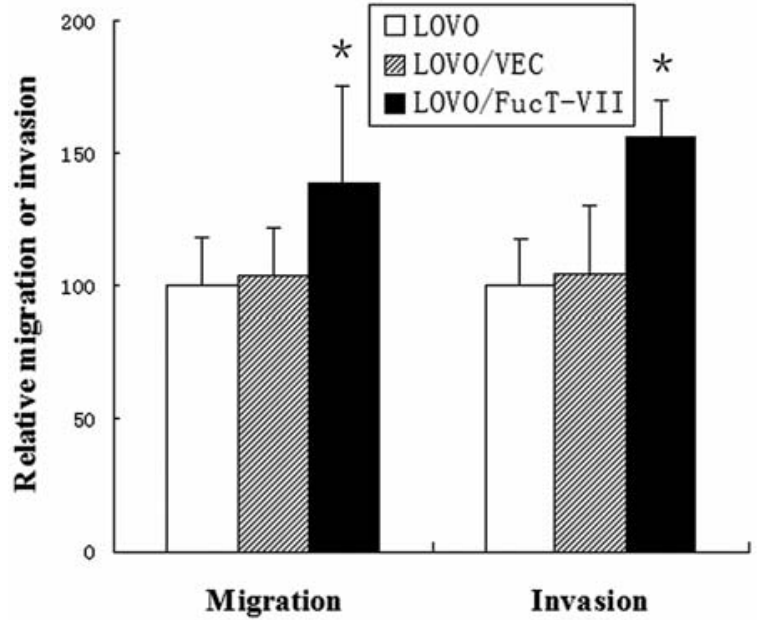

Figure 3. Alteration in cell migration and invasion after the transfection of FucT-VII gene. Date are expressed as the mean \pm SD of three independent experiments. ${ }^{*} \mathrm{P}<0.05$ compared with the LOVO group. Experimental procedures are described in Materials and methods.

and chemotactic invasion through matrigel was elevated to 138.4 and $156.4 \%$, respectively, as compared with the control LOVO cells. The effect in metastatic potential of the mock transfection was not detected (Fig. 3). However, the changes in cell growth rate and cell cycle after transfection in LOVO cells were slight (data not shown).

a1,3 FucT-VII promoted the expression of CD24 and sialyl Lewis X. CD24 is regarded as a tumor-related protein (9). We also found that there was a high expression of CD24 in colorectal carcinoma (90\% cytoplasmic positive) and strong association of cytoplasmic CD24 with serous layer invasion, tumor stage (pT) and nodal metastasis through immunostaining analysis (Table III).

The positive correlation between mRNA expression of $\alpha 1,3$ FucT-VII and CD24 was found in the colorectal cancer tissue via RT-PCR (Spearman's rho $=0.4435, \mathrm{p}=0.014$ ). However, the correlation at protein expression level did not reach statistical significance.

In vitro, we found that LOVO/FucT-VII exhibited a higher mRNA expression of CD24 than mock-transfected or control cells, besides, LOVO/FucT-VII also exhibited a higher protein expression of $\mathrm{CD} 24$, which was confirmed by cell immunostaining and FACS (Fig. 4).

We next investigated the alteration of glycosylation after FucT-VII transfection. Richer SLe ${ }^{\mathrm{X}}$ (the only product of $\alpha 1,3$ FucT-VII) carbohydrate epitope at the cell surface was also observed by FACS sorting using the SLe ${ }^{\mathrm{X}}$-specific $\mathrm{mAb}$ KM93 (Fig. 5).

\section{Discussion}

$\alpha 1,3$ FucT-VII was first cloned from THP-1 cDNA library in 1993 by Sasaki et al (8). Then, Natsuka and his colleagues cloned the cDNA of $\alpha 1,3$ FucT-VII through cross hybridization, and the only product was SLe ${ }^{\mathrm{X}}$ instead of $\mathrm{Le}^{\mathrm{X}}$ by using FACS sorting in FucT-VII stably expressing cells (25). $\alpha 1,3$ FucT-VII is located on human chromosome $9 q 34.3$, the open reading frame encoding 342 amino acids. Comparing to FucT-III and FucT-V, the sequence of Fuc-TVII had 42-43\% identity, while $47 \%$ identity with the sequence of FucT-VI. $\alpha 1,3$ FucT-VII was type II transmembrane TOPO structure, composing of a small N-terminal cytoplasmic tail of 14 amino acids, a membrane-spanning region of 19 amino acids and a catalytic domain oriented lumenally in the Golgi apparatus with 309 amino acids (8). $\alpha 1,3$ FucT-VII was found 
Table III. Associations between cytoplasmic CD24 expression and clinicopathological variables.

\begin{tabular}{|c|c|c|c|c|c|}
\hline \multirow[b]{2}{*}{ Characteristic } & \multicolumn{4}{|c|}{$\mathrm{cCD} 24$} & \multirow[b]{2}{*}{ P-value } \\
\hline & Negative & Weak & Moderate & Strong & \\
\hline & 3 & 6 & 13 & 8 & \\
\hline \multicolumn{6}{|l|}{ Age (years) } \\
\hline$<60$ & 3 & 3 & 8 & 4 & $0.384^{\mathrm{a}}$ \\
\hline$\geq 60$ & 0 & 4 & 4 & 4 & \\
\hline \multicolumn{6}{|l|}{ Differentiation } \\
\hline High & 1 & 1 & 2 & 1 & $0.945^{b}$ \\
\hline Moderate & 2 & 3 & 8 & 5 & \\
\hline Low & 0 & 2 & 3 & 2 & \\
\hline \multicolumn{6}{|c|}{ Serous layer invasion } \\
\hline No & 2 & 4 & 3 & 0 & $0.015^{\mathrm{a}}$ \\
\hline Yes & 1 & 2 & 10 & 8 & \\
\hline \multicolumn{6}{|l|}{ Dukes } \\
\hline A & 2 & 3 & 2 & 0 & $0.171^{\mathrm{b}}$ \\
\hline $\mathrm{B}$ & 1 & 2 & 3 & 1 & \\
\hline $\mathrm{C}$ & 0 & 1 & 4 & 3 & \\
\hline $\mathrm{D}$ & 0 & 0 & 4 & 4 & \\
\hline \multicolumn{6}{|l|}{ Tumor stage } \\
\hline $\mathrm{pT}_{1-2}$ & 2 & 4 & 2 & 0 & $0.032^{\mathrm{b}}$ \\
\hline $\mathrm{pT}_{3}$ & 1 & 1 & 5 & 2 & \\
\hline $\mathrm{pT}_{4}$ & 1 & 0 & 6 & 6 & \\
\hline \multicolumn{6}{|l|}{ Nodal status } \\
\hline $\mathrm{pN}_{0}$ & 3 & 5 & 5 & 2 & $0.048^{\mathrm{a}}$ \\
\hline $\mathrm{pN}_{1-2}$ & 0 & 1 & 8 & 6 & \\
\hline \multicolumn{6}{|c|}{ Distant metastasis } \\
\hline $\mathrm{pM}_{0}$ & 3 & 6 & 9 & 4 & $0.177^{\mathrm{a}}$ \\
\hline $\mathrm{pM}_{1}$ & 0 & 0 & 4 & 4 & \\
\hline \multicolumn{6}{|l|}{ Grade } \\
\hline I & 2 & 3 & 1 & 0 & $0.107^{b}$ \\
\hline II & 1 & 2 & 3 & 1 & \\
\hline III & 0 & 1 & 4 & 3 & \\
\hline IV & 0 & 0 & 4 & 4 & \\
\hline
\end{tabular}

${ }^{\mathrm{a}}$ Fisher's exact test; ${ }^{\mathrm{b}} \chi^{2}$ test for trend.

to be expressed in a series of hematopoietic cells and HEV, and could be transfected to different cells, such as COS-1, Namalwa and BHK-21 cells, and could be obtained from protein A fusion protein (26).

The expression of FucT-VII in colon cancer tissues remained unclear. A previous study reported that Fuct-VII gene was expressed at a very low level, compared to other FucTs, in particular FucT-III (27). However, the FucT-VII transcript was detected to be elevated in colon cancer by real-time PCR in recent studies $(28,29)$, and it was also accepted that the total FucT activity in colon cancer was contributed by several independently regulated genes (29). In the current study, we found the mRNA and protein expression levels of FucT-VII were significantly higher in tumor tissue than that in normal tissue. The data indicated that FucT-VII might be another important gene which had special regulating mechanism in colorectal cancer. A positive correlation between FucT-VII expression and lymph node status together with grade stage was observed both in the mRNA and protein level. Therefore, we concentrated on 
A

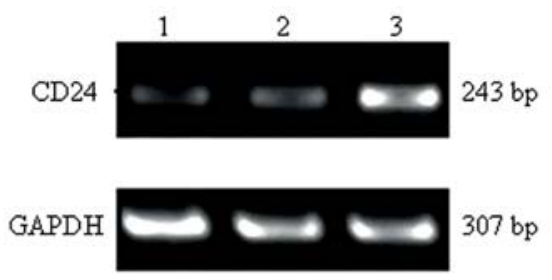

C

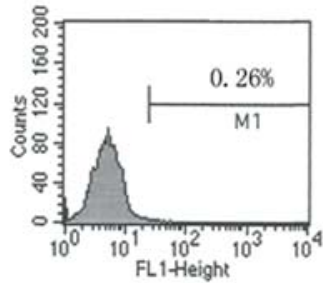

(-) Control
B

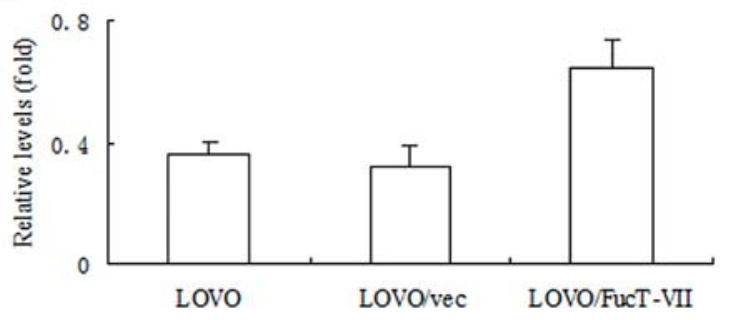

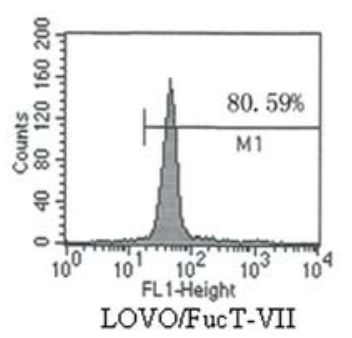

D
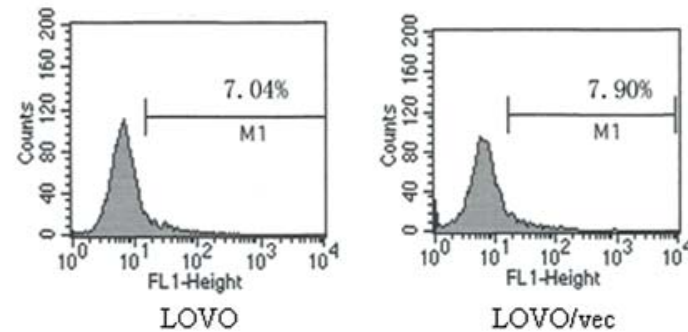

LOVO/FucT-VII

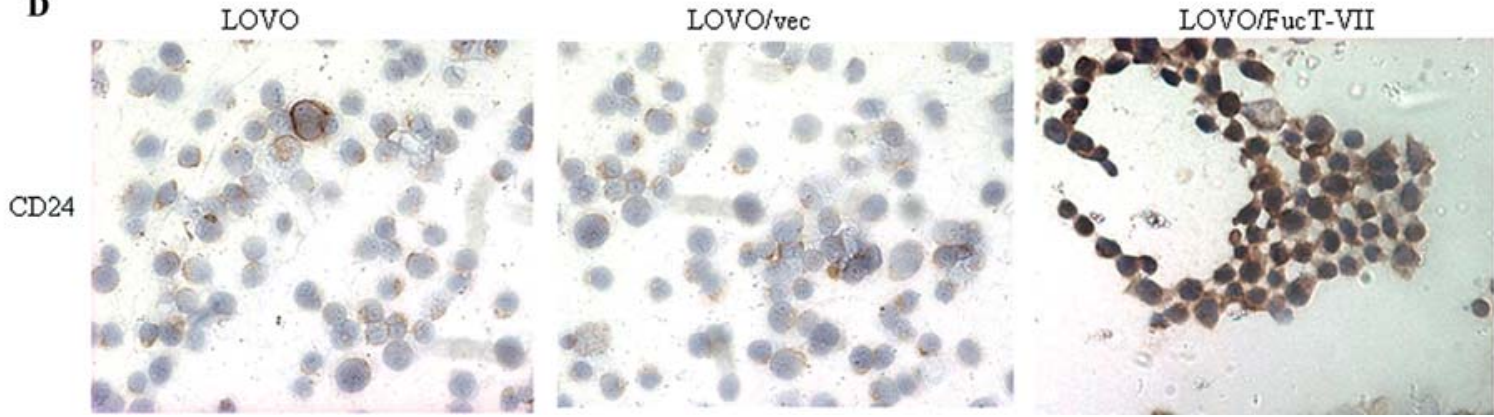

Figure 4. Expression of CD24 in FucT-VII-transfected LOVO cells. (A) RT-PCR. Lane 1, LOVO; Lane 2, LOVO/vec; Lane 3, LOVO/FucT-VII. (B) The relative expression of CD24 mRNA. Representative quantitation of three independent experiments. The error bars represent the SE. (C) Flow cytometry. (-) Control, without the addition of the first antibody. (D) Cell immunostaining (x100).
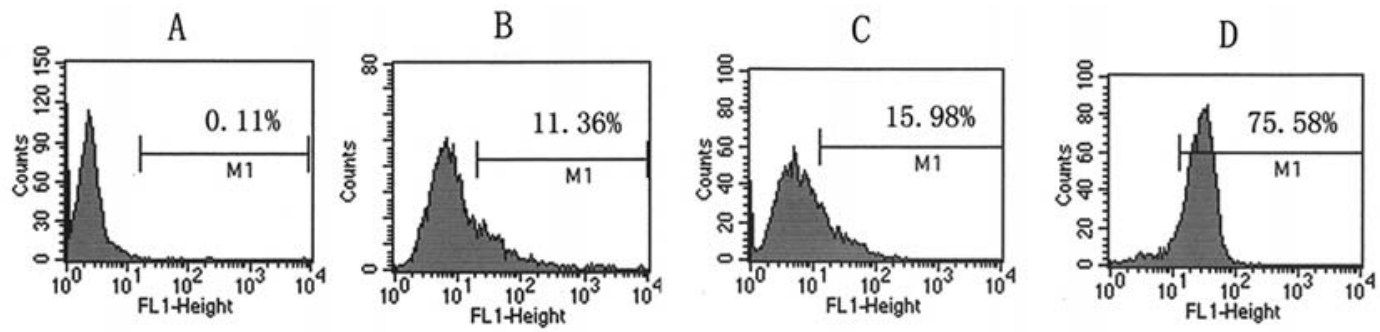

Figure 5. Cytoflurographic analysis of transfected cells using mAb specific for the sialyl Lewis X (KM93). (A) Negative control, without the addition of the first antibody; (B) LOVO cells; (C) LOVO/vec cells; (D) LOVO/FucT-VII.

FucT-VII gene, especially its correlation with tumor metastases. Although the sample size of the clinical specimens was not large, we examined both the tumor tissue and adjacent normal tissue of each patient and found that the correlation and difference reached statistical significance. According to the AJCC stage, stage I patients without lymph node metastasis has a 5-year survival rate of $90 \%$, while it was only $50 \%$ in stage III patients with a positive lymph node status (30). Lymph node metastasis is an ominent prognostic factor, and adjuvant chemotherapy should be conducted in patients of stage III to reduce the risk of recurrence and distant metastases. Although the correlation between the fucosyltransferase and disease-free survival or overall survival has not yet been proved in our study because of inadequate follow-up time, we found the higher expression of FucT-VII in tumor tissue both in transcription and translation levels, more-over, the positive correlation between FucT-VII and lymph node metastases was proved. Therefore, we supposed that the tumors which had high expression of FucT-VII might have a poor prognosis due to its more invasive potential.

We further explored the biological changes of LOVO cells after stable transfection of FucT-VII in vitro. Previous studies showed that the tranfection of FucT-VII into H7721 hepatocarcinoma cells could enhance phosphorylation of retinoblastoma $(\mathrm{Rb})$ protein and facilitate the $\mathrm{G} 1 / \mathrm{S}$ transition and growth rate of the cells through the regulation of CDI 
p27 ${ }^{\text {Kipl }}$ protein (31). In our study, we transfected $\alpha 1,3$ FucTVII into human colon cancer cells and yielded a similar result. After transfection, LOVO cells exhibited stronger ability of chemotactic migration and invasion than non-transfected cells. Such changes of metastasis-related phenotype might be correlated to the function of Fuc (fuco-residue) and SA (terminal sialic acid) after the interaction of FucT-VII and glycoprotein substrate. A previous study (32) proved that SA played a more important role in binding tumor cells to HUVEC, and mono-antibody of SLe ${ }^{\mathrm{X}}$ (KM93) was able to block this effect.

Preliminary investigation on the mechanism of FucT-VII promoting metastasis in colorectal cancer was further performed. FucT-VII could fucosylate only a type II acceptor with terminal $\alpha 2,3$-linked sialic acid among different types of oligosaccharides and produced as the only product SLe ${ }^{\mathrm{X}}(16)$. $\mathrm{SLe}^{\mathrm{X}}$ was shown to act as an ominent prognostic factor in breast cancer, colorectal cancer and other malignant tumors $(18,29,33)$. High SLe ${ }^{X}$ expression was observed in 132 colorectal cancer specimens compared with very low expression level of it in normal tissue, and overexpression of $\mathrm{SLe}^{\mathrm{X}}$ predicted high risk of recurrence and poor prognosis (18). The high expression of SLe ${ }^{\mathrm{X}}$ could reflect the metastatic potential in colorectal cancer with liver metastases (34) and could be a prognosis marker. Similar results were also obtained in gastric carcinoma and breast cancer $(33,35)$. To our knowledge, FucT-VII could directly contribute to the enhanced synthesis of $\mathrm{SLe}^{\mathrm{X}}$ or SLe ${ }^{\mathrm{A}}$. CD24 is a molecule deserving considerable attention for its involvement in cell adhesion and metastatic tumor spreading. CD24 positive tumor cells show a better ability to bind to endothelial cells and platelet in the blood stream and thus circulate in the vasculature protecting from immunological system attack (19). Newly-born CD24 peptide could be transported to the cell membrane only after the carbohydrate modification. Moreover, it was shown that CD24 highly expressed in many solid tumors, with a positive rate of $85 \%$ and correlates to tumor pathological stage or lymph node metastasis (19-24). $\mathrm{SLe}^{\mathrm{X}}$-modified CD24 could also act as a P-selectin ligand and be an essential factor for tumor metastases. In colorectal cancer, strong cytoplamic CD24 expression was proved to be significantly correlated to short survival time (23). Whether FucT-VII is mediated by CD24 glycosylation in promoting cancer metastasis was still not clear. Thus, we evaluated the expression of both CD24 and SLe ${ }^{\mathrm{x}}$ in tumor tissue and found a significant correlation between CD24 cytoplasmic protein expression and lymph node metastases, which was consistant with the results of previous studies (23). The positive correlation between FucT-VII and CD24 was confirmed at mRNA level. In vitro, transfection of $\alpha 1,3$ FucT-VII induced an increase of $\mathrm{CD} 24$ expression both at mRNA and protein level, and the carbohydrate product $\mathrm{SLe}^{\mathrm{X}}$ on the cell surface was also up-regulated, indicating that $\alpha 1,3$ FucT-VII might promote metastases by influencing the glycosylation of CD24. CD24 can bind to P-selectin and then help the adhesion of neutrophils or monocytes to activate endothelial cells or platelets, which both express P-selectin. The premetastatic role of CD24 in human tumor cells was suggested to be based on this CD24/P-selectin interaction (36). $\mathrm{SLe}^{\mathrm{X}}$, which serves as the ligand of E-/P-selectin expressed on the surface of vascular endothelial cells, and mediated the adhesion of malignant cells to vascular endothelium by combining with E-/P-selectin, which is the initial step for malignant cells to penetrate through the vessels in the process of metastasis (36-38).

Cancer-cell adhesion to endothelial cells mediated by selectins and their carbohydrate ligands has been proposed to figure heavily in cancer metastases. So the up-regulation of CD24 and SLe ${ }^{\mathrm{x}}$ by $\alpha 1,3$ FucT-VII might be one of the pathways which promote lymph node metastases in colorectal cancer. In this study, we preliminarily investigated the possible correlation between FucT-VII and CD24. Expression levels of other adhesion molecules, such as CD44 and integrins, would be ascertained in the next step in order to elucidate the mechanism.

In conclusion, the data presented here showed that $\alpha 1,3$ FucT-VII was highly expressed in colorectal carcinoma and positively associated with the lymph node metastases in colorectal cancer patients. $\alpha 1,3$ FucT-VII might influence the expression of CD24 and play an essential role in tumor infiltration and metastases. Thus, it could serve as a promising biomarker to predict colorectal carcinoma metastasis or become a therapeutic target in preventing tumor metastases.

\section{Acknowledgements}

This research is supported by the the Clinical and Basic Medicine Cross Fund of Fudan University.

\section{References}

1. Jemal A, Murray T, Ward E, et al: Cancer statistics 2005. CA Cancer J Clin 55: 10-30, 2005.

2. Hakomori S: Tumor malignancy defined by aberrant glycosylation and sphingo (glyco) lipid metabolism. Cancer Res 56: 5309-5318, 1996.

3. Taniguchi N, Miyoshi E, Ko JH, Ikeda Y and Ihara Y: Implication of $\mathrm{N}$-acetylglucosaminyl-transferases III and $\mathrm{V}$ in cancer: gene regulation and signaling mechanism. Biochim Biophys Acta 1455: 287-300, 1999.

4. Yamamoto H, Swoger J, Greene S, et al: $\beta-1,6-\mathrm{N}$-acetylglycosamine bearing $\mathrm{N}$-glycans in human gliomas: implications for a role in regulating invasivity. Cancer Res 60: 134-142, 2000.

5. Guo HB, Zhang Y and Chen HL: Relationship between metastasis-associated phenotypes and N-glycan structure of surface glycoproteins in human hepatocarcinoma cells. J Cancer Res Clin Oncol 127: 231-236, 2001.

6. Liu F, Zhang Y, Zhang XY and Chen HL: Transfection of the nm23-H1 gene into human hepatocarcinoma cell line inhibits the expression of sialyl Lewis X, alpha1,3 fucosyltransferase VII, and metastatic potential. J Cancer Res Clin Oncol 128: 189-196, 2002.

7. Narimatsu H: Human fucosyltransferases: tissue distribution of blood group antigens, cancer-associated antigens and fucosyltransferases. Tanpakushitsu Kakusan Koso 43: 2394-2403, 1998.

8. Sasaki K, Kurata K, Funayama K, et al: Expression cloning of a novel alpha 1,3-fucosyltransferase that is involved in biosynthesis of the sialyl Lewis $\mathrm{x}$ carbohydrate determinants in leukocytes. J Biol Chem 269: 14730-14737, 1994.

9. Zhao YY, Takahashi M, Gu JG, Miyoshi E, Matsumoto A, Kitazume $\mathrm{S}$ and Taniguchi N: Functional roles of N-glycans in cell signaling and cell adhesion in cancer. Cancer Sci 99: 1304-1310, 2008.

10. Muinelo-Romay L, Vázquez-Martín C, Villar-Portela S, Cuevas E, Gil-Martín E and Fernández-Briera A: Expression and enzyme activity of alpha(1,6)fucosyltransferase in human colorectal cancer. Int J Cancer 123: 641-646, 2008. 
11. Petretti T, Kemmner W, Schulze B and Schlag PM: Altered mRNA expression of glycosyltransferases in human colorectal carcinomas and liver metastases. Gut 46: 359-366, 2000.

12. Martinez M, Joffraud M, Giraud S, Baïsse B, Bernimoulin MP, Schapira M and Spertini O: Regulation of PSGL-1 interactions with L-selectin, P-selectin and E-selectin: role of human fucosyltransferase-IV and -VII. J Biol Chem 280: 5378-5390, 2005.

13. Ding KF and Zheng S: Study on relationship of fucosyltransferase gene types in breast cancer with metastasis and prognosis. Zhonghua Wai Ke Za Zhi 42: 546-550, 2004.

14. Barthel SR, Gavino JD, Wiese GK, Jaynes JM, Siddiqui J and Dimitroff CJ: Analysis of glycosyltransferase expression in metastatic prostate cancer cells capable of rolling activity on microvascular endothelial (E)-selectin. Glycobiology 18: 806-817, 2008.

15. Martín-Satué M, De Castellarnau C and Blanco J: Overexpression of alpha(1,3)-fucosyltransferase VII is sufficient for the acquisition of lung colonization phenotype in human lung adenocarcinoma HAL-24Luc cells. Br J Cancer 80: 1169-1174, 1999.

16. Qi HL, Zhang Y, Ma J, Guo P, Zhang XY and Chen HL: Insulin/ protein kinase $B$ signalling pathway up-regulates metastasisrelated phenotypes and molecules in H7721 human hepatocarcinoma cell line. Eur J Biochem 270: 3795-3805, 2003.

17. Liu F, Zhang Y, Zhang XY and Chen HL: Transfection of the nm23-H1 gene into human hepatocarcinoma cell line inhibits the expression of sialyl Lewis $\mathrm{X}$, alpha1,3 fucosyltransferase VII, and metastatic potential. J Cancer Res Clin Oncol 128: 189-196, 2002.

18. Nakamori S, Kameyama M, Imaoka S, et al: Increased expression of sialyl Lewis $X$ antigen correlates with poor survival in patients with colorectal carcinoma: clinicopathological and immunohistochemical study. Cancer Res 53: 3632-3637, 1993.

19. Friederichs J, Zeller Y, Hafezi-Moghadam A, Gröne HJ, Ley K and Altevogt P: The CD24/P-selectin binding pathway initiates lung arrest of human A125 adenocarcinoma cells. Cancer Res 60: 6714-6722, 2000 .

20. Fogel M, Friederichs J, Zeller Y, et al: CD24 is a marker for human breast carcinoma. Cancer Lett 143: 87-94, 1999.

21. Kristiansen G, Schlüns K, Yongwei Y, Denkert C, Dietel M and Petersen I: CD24 is an independent prognostic marker of survival in non-small cell lung cancer patients. Br J Cancer 88: 231-236, 2003.

22. Choi YL, Kim SH, Shin YK, Hong YC, Lee SJ, Kang SY and Ahn G: Cytoplasmic CD24 expression in advanced ovarian serous borderline tumor. Gynecol Oncol 97: 379-386, 2005.

23. Weichert W, Denkert C, Burkhardt M, et al: Cytoplasmic CD24 expression in colorectal cancer independently correlates with shortened patient survival. Clin Cancer Res 11: 6574-6581, 2005.

24. Sagiv E, Kazanov D and Arber N: CD24 plays an important role in the carcinogenesis process of the pancreas. Biomed Pharmacother 60: 280-284, 2006.

25. Natsuka S, Gersten KM, Zenita K, Kannagi R and Lowe JB: Molecular cloning of a cDNA encoding a novel human leukocyte alpha-1,3-fucosyltransferase capable of synthesizing the sialyl Lewis x determinant. J Biol Chem 269: 16789-16794, 1994.
26. Shinoda K, Morishita Y, Sasaki K, Matsuda Y, Takahashi I and Nishi T: Enzymatic characterization of human alpha1,3-fucosyltransferase Fuc-TVII synthesized in a B cell lymphoma cell line. J Biol Chem 272: 31992-31997, 1997.

27. Kudo T, Ikehara Y, Togayachi A, et al: Up-regulation of a set of glycosyltransferase genes in human colorectal cancer. Lab Invest 78: 797-811, 1998.

28. Koike T, Kimura N, Miyazaki K, et al: Hypoxia induces adhesion molecules on cancer cells: a missing link between Warburg effect and induction of selectin-ligand carbohydrates. Proc Natl Acad Sci USA 101: 8132-8137, 2004.

29. Malagolini N, Santini D, Chiricolo M and Dall'Olio F: Biosynthesis and expression of the Sda and sialyl Lewis $\mathrm{x}$ antigens in normal and cancer colon. Glycobiology 17: 688-697, 2007.

30. O'Connell JB, Maggard MA and Ko CY: Colon cancer survival rates with the new American Joint Committee on Cancer sixth edition staging. J Natl Cancer Inst 96: 1420-1425, 2004.

31. Wang QY, Guo P, Duan LL, Shen ZH and Chen HLL: Alpha 1,3-fucosyltransferase-VII stimulates the growth of hepatocarcinoma cells via cyclin dependent kinase inhibitor p27Kipl. Cell Mol Life Sci 62: 171-178, 2005.

32. Zhang Y, Zhang XY, Liu F, Qi HL and Chen HL: Relationship between terminal sialyl and fucosyl residues of glycans on cell surface and cell biological behaviors. Shi Yan Sheng Wu Xue Bao 35: 271-277, 2002.

33. Jeschke U, Mylonas I, Shabani N, Kunert-Keil C, Schindlbeck C, Gerber B and Friese K: Expression of sialyl Lewis X, sialyl Lewis A, E-cadherin and cathepsin-D in human breast cancer: immunohistochemical analysis in mammary carcinoma in situ, invasive carcinomas and their lymph node metastasis. Anticancer Res 25: 1615-1622, 2005.

34. Ono M, Sakamoto M, Ino Y, Moriya Y, Sugihara K, Muto T and Hirohashi S: Cancer cell morphology at the invasive front and expression of cell adhesion-related carbohydrate in the primary lesion of patients with colorectal carcinoma with liver metastasis. Cancer 78: 1179-1186, 1996.

35. Ura H, Denno R, Hirata K, Yamaguchi K, Yasoshima T and Shishido T: Close correlation between increased sialyl-Lewis $\mathrm{X}$ expression and metastasis in human gastric carcinoma. World J Surg 21: 773-776, 1997.

36. Aigner S, Sthoeger ZM, Fogel M, et al: CD24, a mucin-type glycoprotein, is a ligand for P-selectin on human tumor cells. Blood 89: 3385-3395, 1997.

37. Varik A: Selectin ligands. Proc Natl Acad Sci USA 91: 73907397, 1994.

38. Takada A, Ohmori K, Yoneda T, Tsuyuoka K, Hasegawa A, Kiso $\mathrm{M}$ and Kannagi R: Contribution of carbohydrate antigen sialyl Lewis A and silalyl Lewis $\mathrm{X}$ to adhesion of human carcinoma cells to vascular endothelium. Cancer Res 53: $354-$ $361,1993$. 